九州大学学術情報リポジトリ

Kyushu University Institutional Repository

\title{
TWO NEW SPECIES OF PROSOPISTEROIDES FROM PAPUA NEW GUINEA (HYMENOPTERA, COLLETIDAE, 13YLAEUS)
}

Hirashima, Yoshihiro

Tadauchi, Osamu

https://doi.org/10.5109/2451

出版情報 : ESAKIA. 21，pp.59-65，1984-02-15. Entomological Laboratory，Faculty of Agriculture， Kyushu University

バージョン :

権利関係 : 


\title{
TWO NEW SPECIES OF PROSOPISTEROIDES FROM PAPUA NEW GUINEA (HYMENOPTERA, COLLETIDAE, HYLAEUS) ${ }^{1 / 2)}$
}

\author{
Yoshiniro Hirashima and Osamu Tadauchi \\ Entomological Laboratory, Faculty of Agriculture, \\ Kyushu University, Fukuoka 812, Japan
}

\begin{abstract}
Two new species of the subgenus Prosopisteroides of the genus Hylaeus, margaretae and paradisicola, are described and the male characters of Prosopisteroides are discussed.
\end{abstract}

The subgenus Prosopisteroides of the genus Hylaeus is endemic to New Guinea and shows very interesting characters (Hirashima, 1967). It has been known by the female of two species only. We were able to collect two new species of this subgenus including the male during our 1982 expedition to Papua New Guinea. It is very interesting to note that the male of Prosopisteroides is provided with the diagnostic characters common with the female.

Now, Prosopisteroides is represented by four species. The descriptions of new species are given below.

\section{Genus Hylaeus Fabricius}

\section{Subgenus Prosopisteroides Hirashima}

Hirashima, 1967, p. 134 .

Type-species : Hylaeus heteroclitus Hirashima, 1967.

The male is new to science. It is provided with the characters common with female, as follows:

Maxillary palpus extraordinarily elongate (longer than thorax in margaretae, new species), preoccipital carina present, and propodeum long, rounded posteriorly, with propodeal enclosure large, long, subhorizontal, almost all dorsal, smooth and shining.

1) Contribution from the Entomological Laboratory, Faculty of Agriculture, Kyushu University, Fukuoka (Ser. 3, No. 143).

2) Partial result of Grants-in-Aid for Overseas Scientific Survey, Nos. 57041039 and 58043039 from the Ministry of Education, Science and Culture to Y. Hirashima. 
The male of margaretae, new species, is also distinctive in having the mandible bidentate, head rounded in frontal view, clypeo-ocular distance broad (about as broad as antenna1 socket), thorax long and cylindrical (as in the females of other species), metasoma cylindrical, 2nd tergum shorter than 1st and also 3rd, and metasomal sterna normal (unmodified) except 3rd and 4th. Unlike the female, the longitudinally finely striated area lateral to the spiracle on the 2nd tergum is absent.

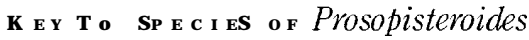

1. Female

- Male: length about $6 \mathrm{~mm}$; head and thorax brilliantly blue-green; metasoma darker blue-green with distinct purple tint; lateral stripes of face, round mark on lower portion of clypeus and antero-basal stripes on mandibles pale yellow or ivory ; underside of flagellum broadly yellowish brown; thorax without yellow markings ; thorax and metasoma cylindrical ; propodeal enclosure large, smooth, strongly shining; fore wing with 1st submarginal cell receiving 1 st recurrent vein near end of cell (before cubital vein)

margaretae, new species

2. Brilliantly metallic blue-green species ; face without yellow markings; propodeal enclosure weakly tessellate or weakly shagreened, shining ; length slightly over $6 \mathrm{~mm}$; known from Mt. Wilhelm (Keglsugl, $2700 \mathrm{~m}$ )

gressitti Hirashima

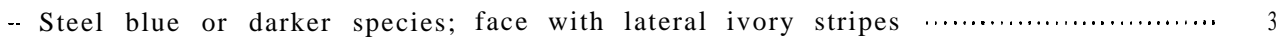

3. Larger, length about $7 \mathrm{~mm}$; head and thorax steel blue, well shining; mesoscutum strongly punctate on finely tessellate ground ; propodeal enclosure not smooth, rather coarsely sculptured; known from Eliptamin Valley

heteroclitus Hirashima

- Smaller, length 5-6 mm; head and thorax dark blue with slight brassy reflection in some light, slightly shining ; mesoscutum weakly punctate on tessellate ground; propodeal enclosure finely tessellate, nearly dull or only weakly shining; known from Baiyer River Birds of Paradise Sanctuary...........

paradisicola, new species

\section{Hylaeus (Prosopisteroides) margaretae, new species}

Male: Length about $6 \mathrm{~mm}$; length of fore wing, about $5 \mathrm{~mm}$; length of maxillary palpus, about $3 \mathrm{~mm}$.

Relative head measurements : length, 23.5; width, 24.5 ; eye length, 17.5; upper interocular distance, slightly over 14.0; width of face, slightly less than 16.0; lower interocular distance, 10.0 ; length of clypeus, 8.0.

Head rather small for the size of insect, rounded in frontal view; inner eye margins strongly converging below except upper about one-third; apex of clypeus only slightly exceeding beyond a line tangential to lower ends of eyes ; mandible short, bidentate ; maxillary palpus extraordinarily elongate, longer than thorax, relative lengths of last four segments, from $3 \mathrm{rd}$ to 6 th, as about 6.5 : 12.5 : 11.5 : 15.0; malar space very narrow ; clypeo-ocular distance broad ; 


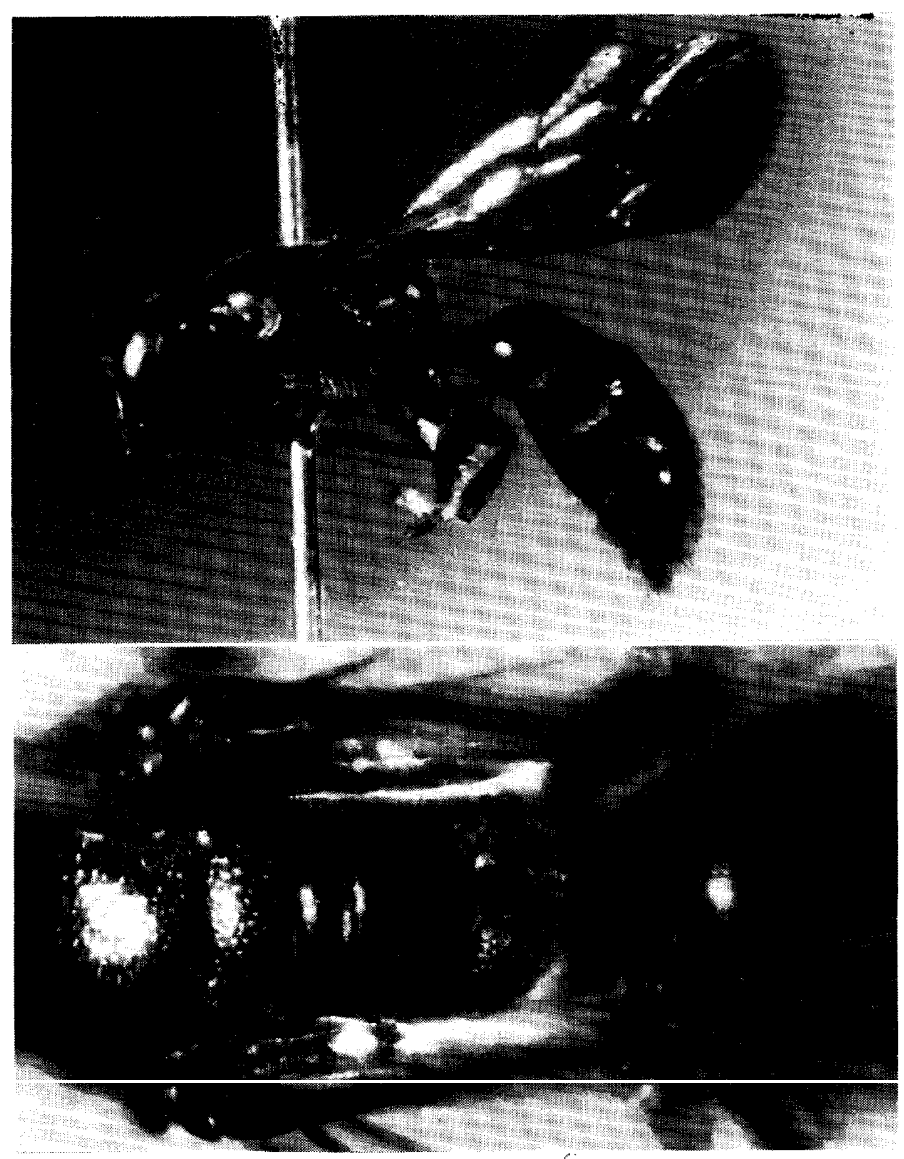

Figs. 1 (above) and 2. Hylaeus (Prosopisteroides) margaretae, new species, holotype male. 1: Lateral view of the body. Note the elongate maxillary palpi. 2: Dorsal view of the thorax and the base of metasoma. Note the long, horizontal and smooth propodeal enclosure.

face flat; frons just below ocelli more or less convex; vertex well exceeding above a line tangential to upper ends of eyes; mid ocellus small ; interocellar distance slightly less than twice as long as lateral ockllus, slightly shorter than ocellocular distance, about as long as ocelloccipital distance; genal area strongly receding below. Antennae rather short; scape shorter than length of clypeus, not swollen, or only slightly thickened at apex; basal segments of flagellum compact ; flagellum with 1 st segment broader than long, 2nd annular, 3rd broader than long, 4th slightly broader than long.

Thorax long, cylindrical; collar of pronotum low, rather thick, more or less rounded laterally; scutellum and metanotum only slightly convex; pro. podeum rather long, rounded posteriorly ; propodeal enclosure large, subhorizontal, apex only on vertical face.

Legs not specially modified; femora slightly swollen; hind legs with tibiae 
not thicker than femora.

Wings with 1st submarginal cell receiving 1st recurrent veins near end of cell (thus, 1st recurrent vein ending before cubital vein) ; 2nd submarginal cell small, receiving 2nd recurrent vein near end of cell.

Metasoma cylindrical; 1st tergum rather long, well convex and rounded mid-basally; 2nd tergum shorter than 1st, well convex, constricted at base ; 3rd tergum longer than 2nd, broadly exposed; 4th about as long as 2nd; 3rd and 4th sterna each with a weak elevation in the middle; no spines or projections at apex of metasoma.

Lower half of face below antennae smooth, shining, with sparse, somewhat longitudinal punctures ; upper half of face above antennae densely punctate, punctures small; space lateral to lateral ocellus smooth, rather coarsely, irregularly punctate; genal area smooth, very shining, with rather weak and sparse punctures. Mesoscutum smooth, very shining, with irregular, shallow punctures; scutellum similar to mesoscutum ; metanotum with minute punctures, nearly smooth; propodeal enclosure smooth, very shining, with an indication of lineolation in some light; mesepisternum smooth, shining, with more or less coarse, rather sparse punctures; lateral face of propodeum shining, very weakly, densely subrugoso-punctate. First tergum more or less densely punctate, punctures very weak; 2nd more punctate than lst, punctures on median portion more or less coarse ; 3rd densely punctate, punctures slightly stronger than those on Ist, weaker than those on 2nd; apical margin of 2nd tergum impunctate, well indicated on median portion.

Color: Head and thorax brilliant blue-green including tegulae and tubercles; mandible blackish, red apically, with yellow stripe on anterior margin basally; malar space blackish or with purple shade; round mark on clypeus and lateral stripes of face nearly ivory; antennae blackish, underside of flagellum broadly yellowish brown. Wings distinctly darkened except basal portions; veins and stigma fuscous. Legs metallic blue-green, with purple shade in some light; anterior faces of fore tibiae broadly ferruginous; fore tarsi and apices of mid tibiae also pale. Metasoma blue-green with distinct purple tint in some light, especially on apical segments.

Pubescence: Hairs on head brownish, not dense; hairs on thorax nearly white ; hairs on mesoscutum very short, sparse, those on lateral face of propodeum not conspicuous. First and 2nd metasomal terga with white, somewhat dense, fringe-like white hairs at sides apically; hairs on 3rd and following segments black; 4th and 5th sterna without transverse fringe of hairs on apical portions.

Type material: Holotype male, on the top of Mt. Kaindi, $2388 \mathrm{~m}$, near Wau, Morobe District, 14-26. VII. 1982 (S. Shinonaga).

Type depository: B. P. Bishop Museum.

Remarks: This is the first male of Prosopisteroides known to science. It 
seems probable that margaretae is a close relative of gressitti, but differs from the latter in having the smoother integument and paler hairs on the thorax.

The wing venation and the relative lengths of the segments of maxillary palpi are also different.

The name of this new species is dedicated to the late Mrs. J. L. Gressitt, who was very helpful to her husband, the founder of Wau Ecology Institute, Wau, Papua New Guinea. She had been very kind to the senior author in many ways since he first met her in Honolulu in 1966.

\section{Hylaeus (Prosopisteroides) paradisicola, new species}

Female: Length 5-6 mm, with more or less short wings.

Relative head measurements : length, 21.0; width, 21.0; eye length, 17.0; upper interocular distance, 12.0; width of face, 14.0; lower interocular distance, 9.0; length of clypeus, a little less than 7.0.

Outline of head rounded as seen in front; inner eye margins distinctly converging below except upper about one-third; apical half of clypeus distinctly depressed (not concave), therefore its outline arched as seen from side; mandible bidentate; maxillary palpi extraordinarily elongate as usual for the subgenus, about as long as thorax, relative length of each segments, from base to apex, $3.0: 3.5: 5.0: 7.5: 7.0: 10.5$; mid ocellus distinctly smaller than lateral one ; frons well convex; preoccipital carina sharp, distinct ; genal area narrow, lower portion strongly receding ; malar space linear anteriorly, only slightly widened posteriorly; clypeo-ocular space very narrow on lower portion. Thorax elongate, cylindrical ; collar of pronotum thick, lateral portion rounded. flattened dorsally; mesoscutum long, slightly convex ; scutellum more or less large, flat; metanotum only slightly convex ; propodeum long, rounded posteriorly ; propodeal enclosure large, well convex and almost horizontal, lateral
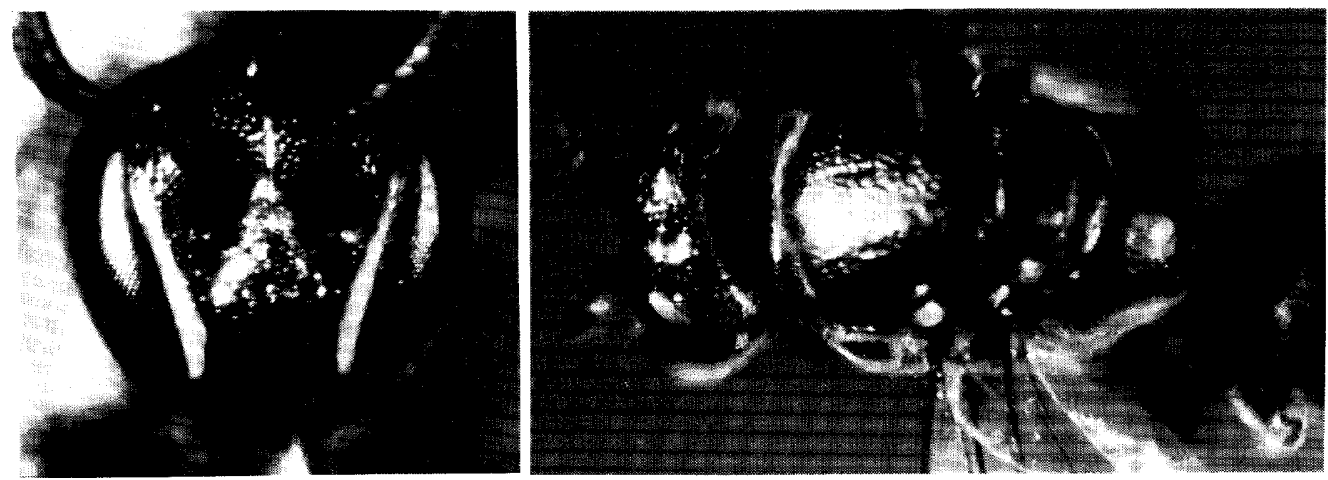

Figs. 3 (left) and 4. Hylaeus (Prosopisteroides) paradisicola, new species, female. 3: Frontal view of the head, 4: Dorso-lateral view of the head and thorax. Note the characteristic propodeum. 
margins not well indicated.

Wings with 1st recurrent veins meeting with cubital vein.

Metasoma rather compact and well convex; three basal terga large.

Clypeus longitudinally weakly rugoso-punctate, sometimes punctures obscure ; supraclypeal area longitudinally lineolate; frons and upper portion of head with distinct, dense punctures, which are sparse on ocellocular space. Mesoscutum weakly and sparsely punctate on distinctly tessellate and nearly dull ground; scutellum similar to mesoscutum, but punctures much smaller, microscopical ; metanotum microscopically shagreened, impunctate ; propodeal enclosure very finely tessellate, nearly dull; propodeum outside enclosure also impunctate, finely sculptured; pre- and 'meso-episterna shining, with weak and sparse punctures; metepisternum and side of propodeum nearly impunctate, very weakly shagreened, almost dull. First metasomal terga smooth, shining (much more shining than thorax), with very fine, rather sparse punctures, median portion of apical margin narrowly impunctate; 2nd tergum smooth, shining like lst, with similar, fine punctures; apical impunctate margin of 2nd tergum more or less broad, well indicated on median portion; 3rd tergum coarsely (but not strongly) rugoso-punctate, punctures much larger than those on 1 st and 2nd.

Color: Head metallic dark blue with brassy tint, shining; narrow lateral stripe of face ivory ; antennae piceous, flagellum beneath reddish brown. Thorax nearly dull except for pre- and meso-episterna ; thorax metallic dark blue, with slight brassy tint dorsally. Wings subhyaline, slightly darkened distally ; veins and stigma fuscous. Legs piceous with strong metallic blue reflection. Metasoma also distinctly metallic dark blue, shining, with purple and brassy shades in some light.

Pubescence:Hairs whitish, very short and sparse on head and thorax; no apical hair fringes on metasomal terga; hairs fuscous on apical metasomal segments.

Type material: Holotype female, and 20 paratopotype females, Baiyer River Birds of Paradise Sanctuary, $1200 \mathrm{~m}$, Western Highland District, Papua New Guinea, 4-8. VIII. 1982 (Y. Hirashima and 0. Tadauchi).

TyPe Depository: Holotype in the Bishop Museum, Honolulu, Hawaii ;paratypes in British Museum (Natural History), London ; Australian National Insect Collection, CSIRO, Canberra ; Department of Primary Industry. Konedobu, Papua New Guinea; and Kyushu University.

REMARKS: Unfortunately the male of this new species is not known.

The female of paradisicola is unique, and is easily separable from that of heteroclitus Hirashima by the smaller size, smoother propodeal enclosure and weaker punctures on the thorax, and that of gressitti Hirashima by the coloration and weaker punctures on the mesoscutum. 


\section{Acknowledgements}

We are grateful to the late Dr. J. L. Gressitt, Director of Wau Ecology Institute, Wau, Dr. A. Allison, Associate Director, Wau Ecology Institute, Mr. Harry Sakulas, Deputy Director, Wau Ecology Institute, Mr. Navu Kwapena, First Assistant Director, Wildlife Division, Boroko, and Dr. J. E. van S. Greve, Senior Entomologist, Department of Primary Industry, Konedobu, for their interests in our project and kind co-operation; to Dr. J. W. Ismay, Entomology Section, Department of Primary Industry, Konedobu, and Dr. G. A. Samuelson, Department of Entomology, Bishop Museum, Honolulu, Hawaii, for their assistance and kind co-operation to our field work; to Dr. S. Shinonaga, Tokyo Medical and Dental University for collecting the type specimen of margaretae, new species ; and to Prof. R. Kano and Prof. T. Nakajima, Tokyo Medical and Dental University for their kind co-operation and helpful suggestion to our project.

\section{References}

Hirashima, Y. 1967. A new subgenus and species of Hylaeus from New Guinea (Hyme-

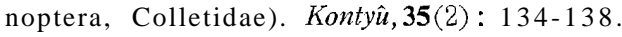

- 1979. Discovery of the second species of Prosopisteroides of New Guinea (Hymenoptera, Colletidae). Esakia, (14) : 145-148.

\section{Addendum}

Very recently Houston (1983) described Euryglossa(Euhesma)tubulifera Houston, n. sp., from western Australia. It is "remarkable for its enormously enlarged maxillary palpi, which cohere to form a slender tube up to $80 \%$ as long as the head and body. The tube functions as a drinking straw, enabling the bees to extract nectar from the essentially bird-adapted flowers of Calothamnus." He also summarizes the phenomena on the enlargement of either the labial or maxillary palpi in several groups of Colletidae.

According to our observation made at Bayier River Birds of Paradise Sanctuary, the female bees of Hylaeus paradisicola do not use the elongated maxillary palpi to suck nectar while they were kept in an aspirator, although they feed on nectar easily in captivity.

Houston, T. F. 1983. An extraordinary new bee and adaptation of palpi for nectar-feeding in some Australian Colletidae and Pergidae (Hymenoptera). J. Aust.ent. Sm., 22: $263-270$. 